
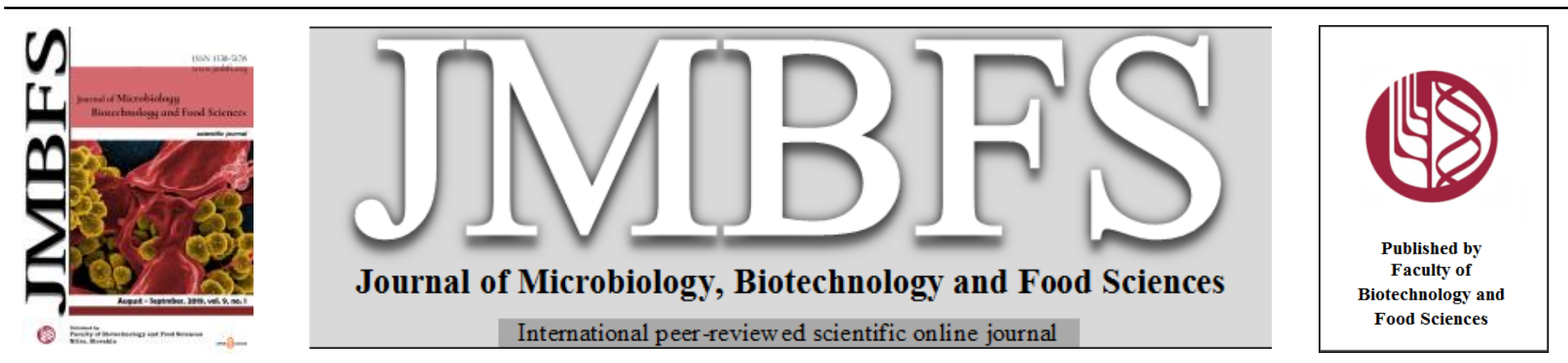

\title{
INFLUENCE OF PARTIAL SUBSTITUTION OF SUGAR WITH SERENDIPITY BERRY (DIOSCOREOPHYLLUM CUMMINSII) EXTRACT ON THE QUALITY ATTRIBUTES AND SHELF-LIFE OF WHEAT BREAD
}

\author{
Rowland Monday Ojo Kayode ${ }^{*}$, Olufunmilola Adunni Abiodun ${ }^{l}$, Sarafa Adeyemi Akeem ${ }^{2}$, Halimat Omodasola Oyeneye ${ }^{l}$ \\ Address(es): Dr. Rowland Monday Ojo Kayode \\ ${ }^{1}$ Division of Food Processing, Preservation, Microbial Biotechnology and Safety, Department of Home Economics and Food Science, University of Ilorin, Nigeria, \\ +2348035850545 . \\ ${ }^{2}$ Department of Food Technology, Faculty of Technology, University of Ibadan, Ibadan, Oyo State, Nigeria, +2347039314405 .
}

*Corresponding author: kayodermosnr@gmail.com; rowland@unilorin.edu.ng

doi: 10.15414/jmbfs.2019.9.1.115-120

\section{ARTICLE INFO}

Received 29. 4. 2018

Revised 15.3. 2019

Accepted 21.3. 2019

Published 1. 8. 2019

Regular article OPEN $\partial_{\text {ACCESS }}$

\begin{abstract}
Serendipity berry (Dioscoreophyllum cumminsii) contains a protein sweetener termed monellin which could be substituted for sugar in foods for diabetics and dieters. Therefore, effects of partial substitution of sugar with serendipity berry extract on quality of white wheat bread were investigated. The pasting properties of wheat flour treated with mixtures of $5 \%$ sugar solution and serendipity berry extract (100:0 control, 80:20, 70:30, 60:40, 50:50 and 40:60) were investigated. Wheat flour were blended with other ingredients and mixtures of $5 \%$ sugar solution and serendipity berry extract to form dough which were allowed to rise prior to baking. Chemical, microbiological and sensory properties of the breads were evaluated. Pasting temperature, peak, final and setback viscosities of the control (sugar solution treated-flour) and serendipity extract treated flour were significantly $(\mathrm{p}<0.05)$ different. Moisture, ash, protein, fat, fibre and carbohydrate contents of the breads ranged from $11.93-15.22 \%, 0.75-3.06 \%, 11.67-14.13 \%, 4.29-9.06 \%, 1.24-2.50 \%$ and $55.01-$ $68.14 \%$, respectively. Although the bacterial $\left(0.0-61 \times 10^{3} \mathrm{cfu} / \mathrm{g}\right)$ and fungal $\left(2.0-76.0 \times 10^{3} \mathrm{cfu} / \mathrm{g}\right)$ counts of the breads increased throughout the 5 days storage period, the serendipity berry extract exerted antimicrobial activities in the treated breads. The proximate, except carbohydrate, of the breads increased while the bacterial and fungal counts decreased with increase in concentration of the serendipity extract. The $60 \%$ serendipity extract treated-bread (mean sensory scores $\geq 8.0$ ) compared favourably with the control (sugar solution treated-bread). This study revealed that $60 \%$ serendipity berry extract could be substituted for sugar for production of high quality bread with extended shelf life.
\end{abstract}

Keywords: Bread, Dioscoreophyllum cumminsii, Preservation, Quality attributes, Substitution, Wheat flour, Sweetener

\section{INTRODUCTION}

The ever increasing consumers' demand for wholesome and safe foods with extended shelf-life and without the use of synthetic preservatives still remains a major challenge to most food industries. The fruit, serendipity berry (Dioscoreophyllum cumminsii), belonging to the family menispermaccae is an unpopular and under-utilized tropical West African indigenous plant (Oselebe and Nwankiti, 2005; Abiodun and Akinoso, 2014). It grows in humid and heavily shaded understorey vegetation of closed forest towards the end of the raining season usually between May and October (Abiodun et al., 2014). It is regarded as a low acid food due to its high $\mathrm{pH}(6.6)$ and low titratable acid values (Abiodun and Akinoso, 2014). Like many other fruits, serendipity berry has high moisture content (80\%) (Abiodun and Akinoso, 2014) which makes it highly perishable. It contains considerable amounts of carotenoids and its vitamin $\mathrm{C}$ content has been reported to be higher than those of local orange, watermelon and banana (Abiodun and Akinoso, 2014). Abiodun and Akinoso (2014) have reported that the fruit contains low quantities of sugars (fructose, glucose and fructose) and alkaloids (solasodine, tomatidenol and soladulcidine) with fructose and soladulcidine being the major sugar and alkaloid, respectively. The intense sweetness of serendipity berry has been attributed to a protein called monellin (Inglett, 1976) which is mainly found in the mucilaginous mesocarp. This protein is the sweetest known naturally occurring substance, up to 3,000 times sweeter than sucrose, and approximately 100,000 times as potent as sugar on a molar basis (Inglett and May, 1969, Faruya et al., 1983, Penarrubia et al., 1992). Therefore, relatively lower concentrations of its extract may be required to achieve desired sweetness and these have facilitated its recommendation for use as a sugar substitute in foods for dieters and diabetics.

Bread is a widely consumed staple food which is mainly produced by baking fermented dough of flour (usually hard wheat), yeast, salt, sugar and water. Other ingredients that may be added include fat, milk and milk products, malt and malt products, oxidants and improvers (such as ascorbic acid and calcium propionate), surfactants and anti-microbial agents (Kučerová, 2015). Bread serves as one of the most important sources of nutrients such as carbohydrate, protein, minerals, fibre, and vitamins in the diets of many people worldwide (Correia et al., 2015) Bread is an appealing, convenient and ready-to-eat food (Correia et al., 2015). These attributes have led to a steady increase in its consumption in most parts of the world including Nigeria. However, the shorter shelf life and perishability nature of bread compared to most other bakery products poses a serious threat in terms of economic loss to its producers as well as its marketers. After production and during storage, bread swiftly loses its freshness and subsequently loses its organoleptic qualities (Pateras, 1999; Ho et al., 2013). Generally, the changes in chemical or physical properties that subsequently resulted in the reduction of the crumb softness during storage time (staling), and spoilage, which result from microbial attack are the two major factors that accelerate the rate of freshness loss in bread (Pateras, 1999). Microbial spoilage of bakery products such as bread is mainly attributed to the growth of moulds (Mentes et al., 2007) which could result to substantial economic loss in the bakery sector and also posing health challenges to consumers owing to the production of mycotoxins.

The detrimental health effects of sucrose-rich diets and consumers' demand for safe products with extended shelf life and without chemical preservatives (Axel et al., 2017), have prompted intensive search for plants with sweetening and preservative properties. Recently, acceptable watermelon juice sweetened with serendipity berry extract was reported to be microbiologically stable within the twelve weeks of storage (Dauda $\boldsymbol{e t}$ al., 2017). The present study was therefore designed to determine the effects of using serendipity berry extract as sugar substitute on the chemical, microbiological, sensory properties and shelf life of wheat flour bread. 


\section{MATERIALS AND METHODS}

\section{Materials}

Fully matured serendipity berry was procured at Esa-Odo farm in Osogbo, Osun state, Nigeria. White wheat flour (Dangote), refined sugar (sucrose), salt, instant dry yeast and fats were procured from a local market (Oja-Oba) in Ilorin, Kwara State, Nigeria. The materials were brought to the food processing laboratory of University of Ilorin, Nigeria for processing and analyses. Distilled water was used throughout the experiment and all reagents used were of analytical grade.

\section{Extraction of juice from serendipity berry fruit}

The serendipity berry juice was extracted as described by Dauda $\boldsymbol{e t}$ al. (2017) The serendipity berry fruits were washed with distilled water to remove dirt. The thoroughly washed fruit was peeled and the seeds were removed. The juice (sweetener) was extracted and strained through double layered muslin cloth to obtain the fresh sweetener. The serendipity berry extract were measured with a measuring cylinder into portions of $60 \mathrm{ml}, 50 \mathrm{ml}, 40 \mathrm{ml}, 30 \mathrm{ml}$ and $20 \mathrm{ml}$ and kept in the refrigerator at $4{ }^{\circ} \mathrm{C}$ for further use.

\section{Preparation of sugar solution}

Five percent $(5 \%)$ sugar solution was prepared by dissolving $50 \mathrm{~g}$ of refined sugar (sucrose) in $500 \mathrm{ml}$ distilled water in a $1000 \mathrm{ml}$ volumetric flask and then made up to mark with distilled water. The solution was kept in the refrigerator at $4{ }^{\circ} \mathrm{C}$ for further use.

\section{Pasting properties of serendipity berry extract-treated flours}

In order to examine the effect of partial substitution of sugar with serendipity berry extract on the pasting properties of wheat flour, six $25 \mathrm{ml}$ of mixtures of 5 $\%$ sugar solution and serendipity berry extract (100:0, 80:20, 70:30, 60:40, 50:50 and 40:60) were prepared separately and their respective treated flour were coded $\mathrm{SSB}_{0} \mathrm{~F}, \mathrm{SSB}_{2} \mathrm{~F}, \mathrm{SSB}_{3} \mathrm{~F}, \mathrm{SSB}_{4} \mathrm{~F}, \mathrm{SSB}_{5} \mathrm{~F}$ and $\mathrm{SSB}_{3} \mathrm{~F}$. Pasting properties of the flour samples were determined using a Rapid Visco Analyzer (RVA Model 3c, Newport Scientific PTY Ltd, Sydney) as described by Arise et al. (2017) with little modification. Briefly, $2.5 \mathrm{~g}$ of each flour sample was accurately weighed into a previously dried empty canister and $25 \mathrm{ml}$ of sugar solution or mixture of sugar solution and serendipity berry extract was added. Samples were transferred onto the water surface of the canister after which the paddle was placed into the canister. The mixture was thoroughly mixed by the paddle fitted at the centre of the canister and the canister was fitted into the Rapid Visco Analyzer. Peak viscosity (RVU), Peak time (min), Peak temperature $\left({ }^{\circ} \mathrm{C}\right)$, Trough (RVU), pasting temperature $\left({ }^{\circ} \mathrm{C}\right)$ and final viscosity (RVU) were read on the instrument while breakdown and setback viscosities (RVU) were calculated.

\section{Formulations for serendipity berry extract sweetened-bread}

Six different samples $\left(\mathrm{SSB}_{0}, \mathrm{SSB}_{2}, \mathrm{SSB}_{3}, \mathrm{SSB}_{4}, \mathrm{SSB}_{5}\right.$ and $\left.\mathrm{SSB}_{6}\right)$ of bread were produced from various recipe formulations as shown in Table 1 . Sample $\mathrm{SSB}_{0}$ served as the control while other samples were treated with serendipity berry extract at different concentrations.

Table 1 Recipe for the production of Serendipity berry extract-sweetened breads

Treatment samples of the serendipity extract-

\begin{tabular}{llllllc}
\multirow{2}{*}{ Ingredients } & \multicolumn{6}{l}{$\begin{array}{l}\text { Treatment samples of the serendipity extract- } \\
\text { sweetened breads }\end{array}$} \\
\cline { 2 - 7 } & $\mathrm{SSB}_{0}$ & $\mathrm{SSB}_{2}$ & $\mathrm{SSB}_{3}$ & $\mathrm{SSB}_{4}$ & $\mathrm{SSB}_{5}$ & $\mathrm{SSB}_{6}$ \\
\hline Wheat flour $(\mathrm{g})$ & 200 & 200 & 200 & 200 & 200 & 200 \\
Edible salt $(\mathrm{g})$ & 2.5 & 2.5 & 2.5 & 2.5 & 2.5 & 2.5 \\
Yeast $(\mathrm{g})$ & 2.5 & 2.5 & 2.5 & 2.5 & 2.5 & 2.5 \\
Vegetable Fats (g) & 5.0 & 5.0 & 5.0 & 5.0 & 5.0 & 5.0 \\
$5 \%$ sugar & 100 & 80 & 70 & 60 & 50 & 40
\end{tabular}

solution (ml)

$\begin{array}{lllllll}\text { Serendipity berry extract } & 0 & 20 & 30 & 40 & 50 & 60\end{array}$

$(\mathrm{ml})$

$\begin{array}{lllllll}\text { Distilled Water }(\mathrm{ml}) & 30 & 30 & 30 & 30 & 30 & 30\end{array}$

Legend: $\mathrm{SSB}_{0}=100 \mathrm{ml}$ sugar solution, $\mathrm{SSB}_{2}=80 \mathrm{ml}$ sugar solution $+20 \mathrm{ml}$ serendipity berry extract, $\mathrm{SSB}_{3}=70 \mathrm{ml}$ sugar solution $+30 \mathrm{ml}$ serendipity berry extract, $\mathrm{SSB}_{4}=60 \mathrm{ml}$ sugar solution $+40 \mathrm{ml}$ serendipity berry extract, $\mathrm{SSB}_{5}=50$ $\mathrm{ml}$ sugar solution $+50 \mathrm{ml}$ serendipity berry extract, $\mathrm{SSB}_{6}=40 \mathrm{ml}$ sugar solution $+60 \mathrm{ml}$ serendipity berry extract.

\section{Preparation of serendipity berry extract-sweetened breads}

The breads were prepared according to the AACC (2000) straight dough method No 10-10B. The dougsh from each formulation was mixed for $5 \mathrm{~min}$, raised for $30 \mathrm{~min}$, punched for $4 \mathrm{~min}$ and raised for another $30 \mathrm{~min}$. The dough was divided, punched again for $5 \mathrm{~min}$, rounded and moulded. Then it was placed in baking pans and allowed to rise for $60 \mathrm{~min}$ at $30{ }^{\circ} \mathrm{C}$. Loaves were baked for 10 min at $250{ }^{\circ} \mathrm{C}$. The baked loaves were carefully removed from the pans and allowed to cool and packaged in polyethylene bags for analyses. The flow chart for the production of bread sweetened with serendipity berry extract is shown in Figure 1. Figure 2 shows the bread samples produced.

\section{Proximate composition of the bread samples}

The moisture content was determined by AOAC (2000) method, while the ash, crude protein, crude fat, crude fibre and carbohydrate contents of the breads were evaluated using AOAC (1990). Briefly, the oven drying method at $105{ }^{\circ} \mathrm{C}$ for 5 $\mathrm{hr}$ was used for moisture determination. Protein content was determined using the micro-Kjeldahl method for crude protein. Total ash was obtained by igniting $2 \mathrm{~g}$ of sample at $600{ }^{\circ} \mathrm{C}$ for $2 \mathrm{hr}$ using muffle furnace. Crude fat was determined by soxhlet extraction with petroleum spirit as the solvent. Crude fibre was determined using digestion method while carbohydrate was estimated by difference $[100-(\%$ water $+\%$ protein $+\%$ fat $+\%$ ash $+\%$ crude fibre $)]$.

\section{Estimation of energy values of the breads}

The energy values of the breads were estimated using Atwater factors in which the percentage carbohydrate, crude fat and crude protein contents were multiplied by 4,9 and 4, respectively. The energy values of the breads were expressed in $\mathrm{kCal} / \mathrm{g}$.

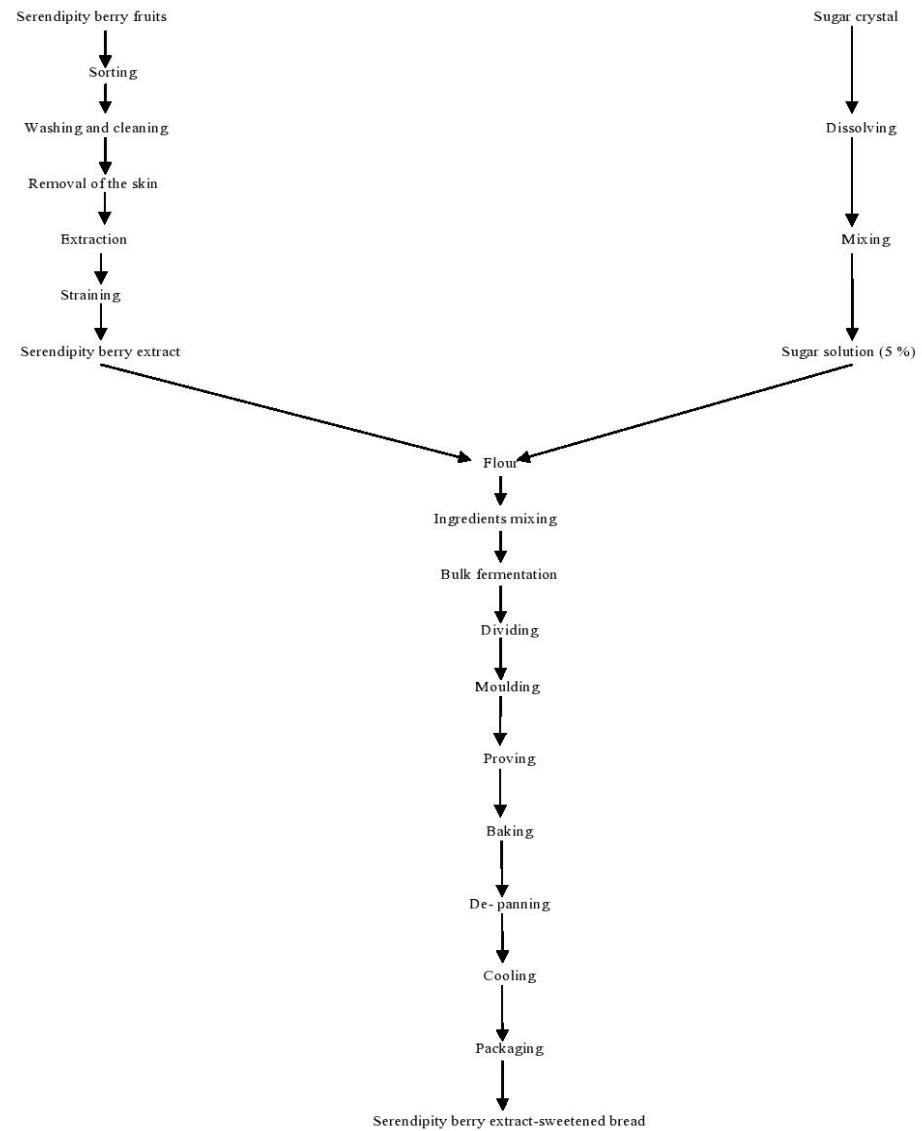

Figure 1 Flowchart for the production of serendipity berry extract-sweetened bread

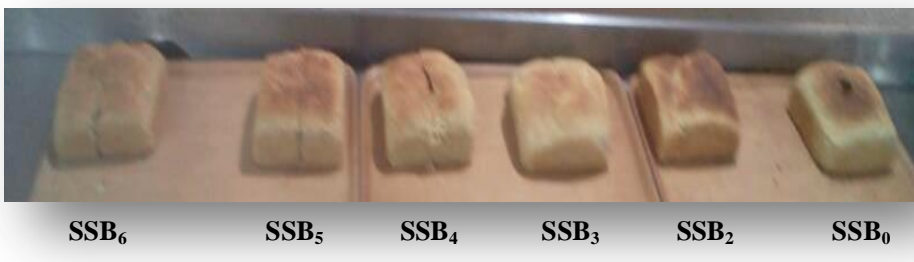

Figure 2 Serendipity berry extract-sweetened breads.

Legend: $\mathrm{SSB}_{0}-100 \mathrm{ml}$ sugar solution treated-bread, $\mathrm{SSB}_{2}-80 \mathrm{ml}$ sugar solution $+20 \mathrm{ml}$ serendipity berry extract treated-bread, $\mathrm{SSB}_{3}-70 \mathrm{ml}$ sugar solution $+30 \mathrm{ml}$ serendipity berry extract treated-bread, $\mathrm{SSB}_{4}-60 \mathrm{ml}$ sugar 
solution $+40 \mathrm{ml}$ serendipity berry extract treated-bread, $\mathrm{SSB}_{5}-50 \mathrm{ml}$ sugar solution $+50 \mathrm{ml}$ serendipity berry extract treated-bread, $\mathrm{SSB}_{6}-40 \mathrm{ml}$ sugar solution $+60 \mathrm{ml}$ serendipity berry extract treated-bread.

\section{Sensory evaluation of the bread samples}

A panel of 20 members who were regular consumers of white wheat bread was selected among students and members of staff of the Department of Home Economics and Food Science, University of Ilorin for the sensory analysis. The panellists were instructed to evaluate the coded bread samples for acceptability of colour, taste, after taste, aroma, crumb texture, crust colour and overal acceptability using a nine point hedonic scale where 1 represented dislike extremely and 9 represented like extremely. The panellists were also instructed to rinse their mouths with drinking water after evaluating each sample.

\section{Determination of total bacterial and fungal counts of the breads}

The total viable bacterial and fungal (yeast and moulds) counts of the bread were determined on days 0, 2 and 5, using the pour plate technique (Adegoke, 2004) One gram of each bread sample was dissolved in $1 \mathrm{ml}$ of $2 \%$ sterile sodium citrate solution in order to prepare a suspension. One millilitre of the suspension was then used for the serial dilution of between $10^{-1}$ and $10^{-3}$. At about $44-50$ ${ }^{\circ} \mathrm{C}, 0.1 \mathrm{ml}$ of the dilution was transferred from each dilution bottle into the corresponding plates and about $15 \mathrm{ml}$ of nutrient agar and potato dextrose agar which were already prepared according to manufacturers' instructions for tota viable bacterial and fungal (yeast and moulds) counts, respectively were poured and mixed thoroughly with the inoculums by rocking the plates. The plates were incubated at $37{ }^{\circ} \mathrm{C}$ for $24 \mathrm{hr}$ and at room temperature $\left(28 \pm 2{ }^{\circ} \mathrm{C}\right)$ for $72 \mathrm{hr}$ for nutrient agar and potato dextrose agar, respectively. Bacterial and fungal colonies were counted using a Stuart scientific colony counter and expressed as colony forming units per gram $(\mathrm{cfu} / \mathrm{g})$ of samples.

\section{Shelf life of the bread samples}

The bread samples were stored under ambient temperature $\left(28 \pm 2{ }^{\circ} \mathrm{C}\right)$ and observed for 10 days. Visual observations for mould growth were carried out on the samples throughout the storage period as stated by Ijah et al. (2014).

\section{Statistical analysis}

Data obtained for the pasting properties of the mixed dough, proximate composition and sensory evaluation of the breads were subjected to one-way analysis of variance (ANOVA) using statistical package for social sciences (SPSS v.16.0) and means were separated using Duncan Multiple Range Test $(\mathrm{p}<0.05)$.

\section{RESULTS AND DISCUSSION}

\section{Pasting properties of serendipity berry extract-treated wheat flour}

The appearance, texture, digestibility and application of starch-based food materials depend largely on their pasting properties (Onweluzo and Nnamuchi, 2009; Ajanaku et al., 2012). The pasting properties of the serendipity berry extract-treated and the control flours are presented in Table 2. The peak viscosity of the flours ranged from 110.7-195.4 RVU for $\mathrm{SSB}_{2} \mathrm{~F}$ and $\mathrm{SSB}_{5} \mathrm{~F}$ respectively. The peak viscosity of the serendipity berry extract treated flours increased with increase in the concentration of the extract up to $50 \%$ substitution level. $\mathrm{SSB}_{2} \mathrm{~F}$ had a significantly $(\mathrm{p}<0.05)$ lower peak viscosity value compared to $\mathrm{SSB}_{0} \mathrm{~F}$ (control) while 30-60\% partial substitution of sugar with serendipity berry extract resulted into significant $(\mathrm{p}<0.05)$ increment in the peak viscosity of the wheat flour. Peak viscosity is the measure of the swelling capacity of starchbased foods soon after heating prior to physical breakdown (Sanni et al., 2006). Starch, starch components such as amylose and amylopectin, and degree of starch damage are some of the factors that could influence the pasting viscosity of flour. Trough viscosity is the minimum viscosity value in the constant temperature phase of RVA which indicates the ability of paste to withstand breakdown during cooling (Ekunseitan et al., 2016). Sample $\mathrm{SSB}_{0} \mathrm{~F}$ had the lowest trough viscosity (79.20 RVU) while $\mathrm{SSB}_{5} \mathrm{~F}$ had the highest (179.4 RVU). Partial substitution of sugar with serendipity berry extract generally increased the trough viscosity of the flour, though the increments were not proportionate with the concentrations of the serendipity berry extract. This result showed the ability of $\mathrm{SSB}_{0} \mathrm{~F}$ paste to withstand breakdown during cooling compared to the pastes of the serendipity berry extract-treated samples.

The breakdown viscosity of the flours ranged between $16.85 \mathrm{RVU}$ for $\mathrm{SSB}_{5} \mathrm{~F}$ and 39.90 RVU for $\mathrm{SSB}_{6} \mathrm{~F}$. No significant difference existed between $\mathrm{SSB}_{4} \mathrm{~F}$ and $\mathrm{SSB}_{0} \mathrm{~F}$ (control). It was observed that 20,30 and $50 \%$ partial substitution of sugar with serendipity berry extract significantly $(\mathrm{p}<0.05)$ decreased the breakdown viscosity of the flour while significant $(p<0.05)$ increase in breakdown viscosity was recorded with $60 \%$ serendipity berry extract substitution. Lower breakdown viscosity is an indication of higher heat and shear stress stability during cooking (Adebowale et al., 2005). Final viscosity indicates the ability of a starch-based food material to form paste after cooling (26). The final viscosity of the flours ranged from 153.85 RVU for $\operatorname{SSB}_{0} \mathrm{~F}$ (control) to $274.7 \mathrm{RVU}$ for $\mathrm{SSB}_{6} \mathrm{~F}$. The final viscosity of the treated flours increased with increase in the concentration of serendipity berry extract and they were significantly $(\mathrm{p}<0.05)$ higher than that of the control $\left(\mathrm{SSB}_{0} \mathrm{~F}\right)$. This implied that the treated flour pastes were less stable after cooling. The lowest $(73.35$ RVU) and the highest (158.45 RVU) setback viscosities were recorded for $\mathrm{SSB}_{0} \mathrm{~F}$ and $\mathrm{SSB}_{6} \mathrm{~F}$ respectively. Significant $(\mathrm{p}<0.05)$ differences existed among the setback viscosities of the flours with the serendipity berry extract-treated flours having higher values than the control $\left(\mathrm{SSB}_{0} \mathrm{~F}\right)$. Higher setback values are synonymous to reduced dough digestibility (Shittu et al., 2001), while lower setback during cooling of the paste indicates lower tendency for retrogradation (Sanni et al., 2001).

Peak time indicates the time required for cooking to be achieved (Adebowale et al., 2005). The peak time recorded for the flours varied between $5.62 \mathrm{~min}$ $\left(\mathrm{SSB}_{2} \mathrm{~F}\right)$ and $6.82 \mathrm{~min}\left(\mathrm{SSB}_{0} \mathrm{~F}\right)$. Partial substitution $(20-60 \%)$ of sugar with serendipity berry extract resulted into decrease in the peak time of the flour, although the peak time obtained for $\mathrm{SSB}_{3} \mathrm{~F}$ and $\mathrm{SSB}_{5} \mathrm{~F}$ were comparable with that of the control $\left(\mathrm{SSB}_{0} \mathrm{~F}\right)$. Hence, partial substitution $(20-60 \%)$ of sugar with serendipity berry extract reduced the time required to cook wheat flour paste. Pasting temperature is the minimum cooking temperature at which there is first observable increase in viscosity due to the swelling of starch granules (Ikegwu et al., 2009; Ekunseitan et al., 2016). The pasting temperature of the flour samples ranged from $89.72{ }^{\circ} \mathrm{C}$ for $\mathrm{SSB}_{0} \mathrm{~F}$ to $95.82{ }^{\circ} \mathrm{C}$ for $\mathrm{SSB}_{6} \mathrm{~F}$. Partial substitution $(20$ $60 \%$ ) with serendipity berry extract significantly increased the pasting temperature of the flour. The highest pasting temperatures were recorded for the flours at 10 and $60 \%$ serendipity berry extract substitution levels. Higher pasting temperatures obtained for the treated flour samples are indication of higher energy cost, low components stability, higher gelatinization tendency and low swelling properties of the starch granules.

Table 2 Effect of serendipity berry extract on the pasting properties of wheat flour

\begin{tabular}{|c|c|c|c|c|c|c|c|}
\hline Sample & $\begin{array}{ll}\text { Peak } & \text { viscosity } \\
\text { (RVU) } & \end{array}$ & $\begin{array}{l}\text { Trough } \\
\text { viscosity (RVU) }\end{array}$ & $\begin{array}{l}\text { Breakdown } \\
\text { viscosity (RVU) }\end{array}$ & $\begin{array}{l}\text { Final viscosity } \\
\text { (RVU) }\end{array}$ & $\begin{array}{l}\text { Setback } \\
\text { viscosity (RVU) }\end{array}$ & Peak time (min) & $\begin{array}{l}\text { Pasting temperature } \\
\left({ }^{\circ} \mathrm{C}\right)\end{array}$ \\
\hline $\mathrm{SSB}_{0} \mathrm{~F}$ & $114.5^{\mathrm{d}} \pm 0.56$ & $79.20^{\mathrm{e}} \pm 0.71$ & $36.90^{\mathrm{b}} \pm 0.71$ & $153.85^{\mathrm{e}} \pm 0.92$ & $73.35^{\mathrm{f}} \pm 0.21$ & $6.82^{\mathrm{a}} \pm 0.35$ & $89.72^{\mathrm{d}} \pm 0.59$ \\
\hline $\mathrm{SSB}_{2} \mathrm{~F}$ & $110.7^{\mathrm{e}} \pm 0.35$ & $82.00^{\mathrm{e}} \pm 2.12$ & $31.90^{c} \pm 0.71$ & $195.4^{\mathrm{d}} \pm 1.06$ & $113.2^{c} \pm 0.57$ & $5.62^{\mathrm{d}} \pm 5.62$ & $95.70^{\mathrm{ab}} \pm 0.63$ \\
\hline $\mathrm{SSB}_{3} \mathrm{~F}$ & $156.4^{\mathrm{b}} \pm 0.14$ & $134.0^{\mathrm{b}} \pm 2.12$ & $23.50^{\mathrm{d}} \pm 0.71$ & $237.4^{\mathrm{c}} \pm 0.71$ & $105.4^{\mathrm{d}} \pm 1.34$ & $6.48^{\mathrm{ab}} \pm 0.22$ & $94.92^{\mathrm{abc}} \pm 0.46$ \\
\hline $\mathrm{SSB}_{4} \mathrm{~F}$ & $166.3^{\mathrm{b}} \pm 0.29$ & $129.3^{\mathrm{c}} \pm 1.27$ & $36.80^{\mathrm{b}} \pm 0.28$ & $252.8^{\mathrm{b}} \pm 0.78$ & $124.2^{\mathrm{b}} \pm 0.42$ & $6.18^{\mathrm{bc}} \pm 0.71$ & $94.18^{\mathrm{bc}} \pm 0.74$ \\
\hline $\mathrm{SSB}_{5} \mathrm{~F}$ & $195.4^{\mathrm{a}} \pm 0.14$ & $179.4^{\mathrm{a}} \pm 0.35$ & $16.85^{\mathrm{e}} \pm 0.92$ & $273.3^{\mathrm{a}} \pm 0.92$ & $93.05^{\mathrm{e}} \pm 1.06$ & $6.50^{\mathrm{ab}} \pm 0.49$ & $94.06^{\mathrm{c}} \pm 0.57$ \\
\hline $\mathrm{SSB}_{6} \mathrm{~F}$ & $155.5^{\mathrm{c}} \pm 0.28$ & $116.5^{\mathrm{d}} \pm 0.01$ & $39.9^{\mathrm{a}} \pm 0.71$ & $274.7^{\mathrm{a}} \pm 1.41$ & $158.45^{\mathrm{a}} \pm 1.63$ & $5.98^{\mathrm{c}} \pm 0.78$ & $95.82^{\mathrm{a}} \pm 0.74$ \\
\hline
\end{tabular}

Values are means of triplicate determinations \pm standard deviation. Means with different superscript in each column are significantly different $(P<0.05)$. $\mathrm{SSB} \mathrm{B}_{0} \mathrm{~F}=100$ $\mathrm{ml}$ sugar solution treated-flour, $\mathrm{SSB}_{2} \mathrm{~F}=80 \mathrm{ml}$ sugar solution $+20 \mathrm{ml}$ serendipity berry extract treated-flour, SSB $\mathrm{F}=70 \mathrm{ml}$ sugar solution $+30 \mathrm{ml}$ serendipity berry extract treated-flour, $\mathrm{SSB}_{4} \mathrm{~F}=60 \mathrm{ml}$ sugar solution $+40 \mathrm{ml}$ serendipity berry extract treated-flour, $\mathrm{SSB}_{5} \mathrm{~F}=50 \mathrm{ml}$ sugar solution $+50 \mathrm{ml}$ serendipity berry extract treated-flour, $\mathrm{SSB}_{6} \mathrm{~F}=40 \mathrm{ml}$ sugar solution $+60 \mathrm{ml}$ serendipity berry extract treated-flour.

Proximate composition and energy values of freshly baked serendipity berry extract-treated bread

Table 3 shows the proximate composition and energy values of the freshly baked serendipity berry extract-treated breads. Moisture content of the breads ranged from $11.93-15.22 \%$ for $\mathrm{SSB}_{2}$ and $\mathrm{SSB}_{6}$ respectively. The values fell within the acceptable moisture limit $(15 \%)$ for dry products (Ijah et al., 2014). Although the moisture content of the treated bread samples generally increased with increase in the concentration of the serendipity berry extract substitution, 20-40 $\%$ partial substitution of sugar with serendipity berry extract resulted into production of breads with lower moisture contents compared to the control $\left(\mathrm{SSB}_{0}\right)$. The significantly highest moisture contents recorded for $\mathrm{SSB}_{5}$ and $\mathrm{SSB}_{6}$ could be attributed to the liquid nature of the serendipity berry extract used as sugar substitute. Olaoye and onilude (2008) have also reported increased in moisture content with increase in the level of breadfruit substitution in wheat breadfruit breads. Moisture content is an indicator keeping quality and high 
moisture could result into shorter shelf life of the breads. Ash is the inorganic material remaining after oxidation of organic matter and it is an indication of the total minerals (Wilson, 1987). The lowest $(0.75 \%)$ and the highest $(3.06 \%)$ ash contents were found in $\mathrm{SSB}_{2}$ and $\mathrm{SSB}_{6}$ respectively. Ash content of the treated bread samples generally increased with increase in the concentration of serendipity berry extract. This increment could be an indication of the presence of higher minerals in the serendipity berry extract. This is plausible because similar trend has also been reported for wheat-breadfruit flour breads (Olaoye and Onilude, 2008) and date palm fruit pulp treated-wheat cookies (Peter $\boldsymbol{e t}$ al. 2017). The ash contents of breads with 30-60\% serendipity berry extract substitution were observed to be higher than $1.43 \%$ recorded for the control. This suggests that the inclusion of serendipity berry extract could boost the mineral content of bread.

The protein content of the breads ranged between $11.67 \%$ for $\mathrm{SSB}_{0}$ (control) and $14.13 \%$ for $\mathrm{SSB}_{6}$. The values of $12.26-14.13 \%$ obtained for the protein content of serendipity berry extract-treated breads were higher than $11.67 \%$ recorded for the control $\left(\mathrm{SSB}_{0}\right)$. This may be due to the high protein content of the serendipity berry extract which must have contributed to the protein content of the whea flour, thus increasing the protein level of the serendipity berry extract treatedbread samples. This is plausible since the sweetness of serendipity berry has been attributed to a protein known as monellin (Wlodawer and Hodgson, 1975; Inglett, 1976). The crude fat of the bread samples ranged from 4.29-9.06 \% with the serendipity berry extract-treated breads recording significantly $(p<0.05)$ higher values than the control $\left(\mathrm{SSB}_{0}\right)$. It was observed that the crude fat of the treated-breads with the exception of $\mathrm{SSB}_{4}$, increased as the concentration of the serendipity berry extract substitution increased. This is an indication of higher fat content in the serendipity berry extract compared to wheat flour. This is similar to the report of Peter et al. (2017) on date palm fruit pulp treated-wheat cookies. High fat content could shorten the shelf life of baked foods such as bread (Ihekoronye and Ngoddy, 1985)
The fibre content of the breads fell within 1.24-2.50\%, recorded for the control $\left(\mathrm{SSB}_{0}\right)$ and $\mathrm{SSB}_{6}$ respectively. The fibre content of the bread samples except $\mathrm{SSB}_{5}$ increased with increase in concentration of the serendipity berry extract substitution. Partial substitution (20-60\%) of sugar with serendipity berry extract generally increased the fibre contents of the breads. Similar trend has been reported by Olaoye and Onilude (2008) for wheat-breadfruit flour breads and Peter et al. (2017) for date palm fruit pulp treated-whole wheat cookies Higher fibre content is advantageous in the diets as it increases faecal output, reduces faecal $\mathrm{pH}$, diabetes, incidence of colon cancer, obesity, heart diseases and certain degenerative diseases (Cummings et al., 1996). The results showed that the carbohydrate content of the breads ranged between $55.01 \%$ and $68.14 \%$. Partial substitution (20-60\%) of sugar with serendipity berry extract resulted into the production of breads with significantly $(\mathrm{p}<0.05)$ lower carbohydrate contents. This could be due to the lower sugar content of serendipity berry (Inglett, 1976; Oselebe and Nwankiti, 2005; Abiodun et al., 2014). It was observed that the carbohydrate content of the treated bread samples generally decreased as the concentration of the substituted serendipity berry extract increased. Similar trends have been reported for wheat-breadfruit flour breads (Olaoye and Onilude, 2008) and date palm pulp meal sweetened bread (Obiegbuna et al., 2013).

\section{Energy values of the bread samples}

The energy values of the bread samples ranged from $352.21-376.83 \mathrm{kCal} / \mathrm{g}$ for $\mathrm{SSB}_{4}$ and $\mathrm{SSB}_{3}$ respectively (Table 3 ). Energy values of the breads significantly $(\mathrm{P}<0.05)$ increased at $20 \%$ and $30 \%$ serendipity berry extract substitution levels but decreased significantly $(\mathrm{P}<0.05)$ at $40 \%$ and $50 \%$ substitution levels compared to the control $\left(\mathrm{SSB}_{0}\right)$. Bhise and Kaur (2014) have also reported reduction in the calorific values of wheat bread with the incorporation of polyols as a sugar substitute. No significant difference existed between the energy values of $\mathrm{SSB}_{6}$ and the control $\left(\mathrm{SSB}_{0}\right)$.

Table 3 Proximate composition and energy values of freshly baked serendipity berry extract-treated breads

\begin{tabular}{|c|c|c|c|c|c|c|c|}
\hline Sample & Moisture (\%) & $\operatorname{Ash}(\%)$ & $\begin{array}{l}\text { Crude protein } \\
(\%)\end{array}$ & $\begin{array}{l}\text { Crude } \\
(\%)\end{array}$ & $\begin{array}{l}\text { Crude fibre } \\
\text { (\%) }\end{array}$ & Carbohydrate & $\begin{array}{ll}\begin{array}{l}\text { Energy } \\
(\mathrm{kCal} / \mathrm{g})\end{array} & \text { value } \\
\end{array}$ \\
\hline $\mathrm{SSB}_{0}$ & $13.50^{\mathrm{b}} \pm 0.38$ & $1.43^{\mathrm{de}} \pm 0.42$ & $11.67^{\mathrm{c}} \pm 0.18$ & $4.29^{\mathrm{d}} \pm 0.37$ & $1.24^{\mathrm{d}} \pm 0.14$ & $68.14^{\mathrm{a}} \pm 1.06$ & $357.85^{\mathrm{c}} \pm 3.03$ \\
\hline $\mathrm{SSB}_{2}$ & $11.93^{\mathrm{c}} \pm 0.09$ & $0.75^{\mathrm{e}} \pm 0.35$ & $12.26^{\mathrm{bc}} \pm 0.19$ & $5.73^{\mathrm{c}} \pm 1.03$ & $1.58^{\mathrm{cd}} \pm 0.24$ & $65.96^{\mathrm{b}} \pm 0.77$ & $364.45^{\mathrm{b}} \pm 1.52$ \\
\hline $\mathrm{SSB}_{3}$ & $12.12^{\mathrm{c}} \pm 0.51$ & $1.75^{\text {cd }} \pm 0.35$ & $13.10^{\mathrm{b}} \pm 0.10$ & $7.87^{\mathrm{ab}} \pm 0.17$ & $1.98^{\mathrm{bc}} \pm 0.21$ & $63.40^{\mathrm{c}} \pm 0.47$ & $376.83^{\mathrm{a}} \pm 1.02$ \\
\hline $\mathrm{SSB}_{4}$ & $13.25^{\mathrm{b}} \pm 0.31$ & $2.26^{\mathrm{bc}} \pm 0.37$ & $12.44^{\mathrm{bc}} \pm 0.16$ & $7.37^{\mathrm{b}} \pm 0.53$ & $2.12^{\mathrm{ab}} \pm 0.17$ & $59.03^{\mathrm{d}} \pm 0.74$ & $352.21^{\mathrm{d}} \pm 1.36$ \\
\hline $\mathrm{SSB}_{5}$ & $15.12^{\mathrm{a}} \pm 1.21$ & $2.75^{\mathrm{ab}} \pm 0.35$ & $12.52^{\mathrm{bc}} \pm 0.91$ & $8.33^{\mathrm{ab}} \pm 0.24$ & $2.11^{\mathrm{ab}} \pm 0.14$ & $57.16^{\mathrm{d}} \pm 0.98$ & $353.69^{\mathrm{d}} \pm 1.68$ \\
\hline $\mathrm{SSB}_{6}$ & $15.22^{\mathrm{a}} \pm 0.22$ & $3.06^{\mathrm{a}} \pm 0.08$ & $14.13^{\mathrm{a}} \pm 0.21$ & $9.06^{\mathrm{a}} \pm 0.17$ & $2.50^{\mathrm{b}} \pm 0.22$ & $55.01^{\mathrm{e}} \pm 0.91$ & $358.10^{\mathrm{c}} \pm 2.12$ \\
\hline
\end{tabular}

Values are means of triplicate determinations \pm standard deviation. Means with different superscript in each column are significantly different $(P<$
0.05). $\mathrm{SSB}_{0}=100 \mathrm{ml}$ sugar solution treated-bread, $\mathrm{SSB}_{2}=80 \mathrm{ml}$ sugar solution $+20 \mathrm{ml}$ serendipity berry extract treated-bread, $\mathrm{SSB}_{3}=70 \mathrm{ml}$ sugar solution $+30 \mathrm{ml}$ serendipity berry extract treated-bread, $\mathrm{SSB}_{4}=60 \mathrm{ml}$ sugar solution $+40 \mathrm{ml}$ serendipity berry extract treated-bread, $\mathrm{SSB}_{5}=50 \mathrm{ml}$ sugar solution $+50 \mathrm{ml}$ serendipity berry extract treated-bread, $\mathrm{SSB}_{6}=40 \mathrm{ml}$ sugar solution $+60 \mathrm{ml}$ serendipity berry extract treated-bread.

Effect of serendipity berry extract on the consumer acceptability of wheat breads

Table 4 shows the mean sensory scores for the colour, taste, after taste, aroma, crumb texture, crust and acceptability of the bread samples. No significant differences existed between the mean scores obtained for the colour, aroma, crumb texture, crust colour and acceptability of $\mathrm{SSB}_{6}$ and the control $\left(\mathrm{SSB}_{0}\right)$ but they were significantly $(\mathrm{p}<0.05)$ higher than the mean values recorded for other bread samples. Also, comparably high mean scores of 8.23 and 8.73 were recorded for the taste of $\mathrm{SSB}_{6}$ and the control $\left(\mathrm{SSB}_{0}\right)$ respectively. The control bread $\left(\mathrm{SSB}_{0}\right)$ had the lowest mean score of 6.73 while $\mathrm{SSB}_{6}$ recorded the highest mean score of 8.53 for after taste. This indicated that the partial substitution $(20$ $60 \%$ ) of sugar with serendipity berry extract positively influenced the after taste of wheat bread samples. The bread $\left(\mathrm{SSB}_{6}\right)$ produced by partially substituting sugar with $60 \%$ serendipity berry extract possessed similar or better sensory attributes (colour, taste, after taste, aroma, crumb texture, crust colour and acceptability) compared to the control bread sample $\left(\mathrm{SSB}_{0}\right)$.

Table 4 Mean acceptability scores of freshly baked serendipity berry extract treated-breads

\begin{tabular}{llllllll}
\hline Sample & Colour & Taste & After taste & Aroma & Crumb texture & Crust colour & Overall acceptability \\
\hline $\mathrm{SSB}_{0}$ & $8.67^{\mathrm{a}} \pm 0.56$ & $8.73^{\mathrm{a}} \pm 1.25$ & $6.73^{\mathrm{bc}} \pm 1.11$ & $8.67^{\mathrm{a}} \pm 1.06$ & $8.70^{\mathrm{a}} \pm 1.34$ & $8.80^{\mathrm{a}} \pm 1.13$ & $8.70^{\mathrm{a}} \pm 1.15$ \\
$\mathrm{SSB}_{2}$ & $7.03^{\mathrm{cd}} \pm 1.29$ & $7.17^{\mathrm{c}} \pm 1.19$ & $7.80^{\mathrm{b}} \pm 1.21$ & $6.73^{\mathrm{d}} \pm 1.49$ & $6.70^{\mathrm{d}} \pm 1.39$ & $6.73^{\mathrm{d}} \pm 1.26$ & $6.83^{\mathrm{d}} \pm 1.16$ \\
$\mathrm{SSB}_{3}$ & $6.77^{\mathrm{d}} \pm 1.31$ & $6.97^{\mathrm{c}} \pm 1.30$ & $7.33^{\mathrm{b}} \pm 1.16$ & $6.43^{\mathrm{d}} \pm 1.20$ & $6.77^{\mathrm{cd}} \pm 1.19$ & $6.67^{\mathrm{d}} \pm 1.27$ & $6.73^{\mathrm{d}} \pm 1.17$ \\
$\mathrm{SSB}_{4}$ & $7.27^{\mathrm{bcd}} \pm 0.79$ & $7.23^{\mathrm{bc}} \pm 0.89$ & $7.87^{\mathrm{b}} \pm 0.94$ & $6.93^{\mathrm{cd}} \pm 0.98$ & $6.93^{\mathrm{cd}} \pm 0.98$ & $7.03^{\mathrm{cd}} \pm 0.77$ & $7.10^{\mathrm{cd}} \pm 0.76$ \\
$\mathrm{SSB}_{5}$ & $7.43^{\mathrm{bcd}} \pm 0.68$ & $7.30^{\mathrm{bc}} \pm 0.59$ & $8.00^{\mathrm{a}} \pm 0.91$ & $7.37^{\mathrm{b}} \pm 0.93$ & $7.33^{\mathrm{bc}} \pm 0.84$ & $7.40^{\mathrm{bc}} \pm 0.81$ & $7.43^{\mathrm{bc}} \pm 0.77$ \\
$\mathrm{SSB}_{6}$ & $8.20^{\mathrm{a}} \pm 0.93$ & $8.23^{\mathrm{ab}} \pm 0.63$ & $8.53^{\mathrm{a}} \pm 1.03$ & $8.13^{\mathrm{a}} \pm 1.07$ & $8.00^{\mathrm{a}} \pm 0.79$ & $8.03^{\mathrm{a}} \pm 0.81$ & $8.37^{\mathrm{a}} \pm 0.67$ \\
\hline $\mathrm{V}^{2}$ & & &
\end{tabular}

Values are means of twenty determinations \pm standard deviation. Means with different superscript in each column are significantly different $(P<0.05) . \mathrm{SSB}_{0}=100 \mathrm{ml}$ sugar solution treated-bread, $\mathrm{SSB}_{2}=80 \mathrm{ml}$ sugar solution $+20 \mathrm{ml}$ serendipity berry extract treated-bread, $\mathrm{SSB}_{3}=70 \mathrm{ml}$ sugar solution $+30 \mathrm{ml}$ serendipity berry extract treated-bread, $\mathrm{SSB}_{4}=60 \mathrm{ml}$ sugar solution $+40 \mathrm{ml}$ serendipity berry extract treated-bread, $\mathrm{SSB}_{5}=50 \mathrm{ml}$ sugar solution +50 ml serendipity berry extract treated-bread, $\mathrm{SSB}_{6}=40 \mathrm{ml}$ sugar solution $+60 \mathrm{ml}$ serendipity berry extract treated-bread.

\section{Microbial counts of serendipity berry extract-treated breads during storage}

Microbial enumerations could be used as indication of food safety and spoilage. The results showing the influence of serendipity berry extract on the bacterial and fungal counts of white wheat breads during 5 days of storage are displayed in Table 5. The bacterial $\left(0.0-61 \times 10^{3} \mathrm{CFU} / \mathrm{g}\right)$ and fungal $\left(2.0-76 \times 10^{3} \mathrm{CFU} / \mathrm{g}\right)$ counts generally increased throughout the 5 days storage period. However, the values were within the safe limits stated by Ihekoronye and Ngoddy (1985) The highest bacterial and fungal counts were recorded for the control bread sample before and during the storage period. In comparison with the control $\left(\mathrm{SSB}_{0}\right)$, the serendipity berry extract treated-breads recorded lower bacterial and fungal counts which were observed to decrease with increase in the concentration of serendipity berry extract substitution Similar trends have been reported for tigernut milk treated with different spices (Kayode $\boldsymbol{e t}$ al., 2017). The generally lower bacterial and fungal counts of the serendipity berry extract treated-breads before and during the storage period could be attributed to the preservative effect of the serendipity berry extract. This is similar to the report of Dauda et al. (2017) on watermelon juice where serendipity berry extract was observed to function as a sweetener and preservative. Bacteria and fungi are the major organisms responsible for the spoilage of bread and their contamination with bread could be from the raw materials used and during processing, handling and storage (Ijah et al., 2014). The antimicrobial activities of serendipity berry extract observed in this study could probably be attributed to the synergetic action of secondary metabolites in the fruit extract. 


\section{Shelf life of serendipity berry extract-treated breads}

The breads produced lasted for 6-8 days prior to observable visible spoilage (Table 5). Breads with $50 \%$ and $60 \%$ serendipity berry extract had the longes storage period of 8 days before visible spoilage was noticed. This might be due to the ability of the serendipity berry extract to inhibit microbial growth. The spoilage observed was indicated by black, yellow, and green coloration on the bread and this was suspected to be mould growth. Incorporation of polyols (glycerol, sorbitol and mannitol) has been reported to extend the shelf life of bread from 4 days to 10 days mainly through moisture retention and relatively water activity stability potentials of the polyols, although packaging materials and storage conditions were shown to be contributory factors to the observed shelf life elongation (Bhise and Kaur, 2014). However, caution must be taken in the use of visual observation in evaluating the shelf life of bread because mycotoxins and off-flavours might have been produced even before fungal outgrowth would be visible (Magan et al., 2003).

$\underline{\text { Table } 5 \text { Effect of serendipity berry extract on the microbial counts and shelf-life of white wheat breads during storage }}$

\begin{tabular}{|c|c|c|c|c|c|c|c|}
\hline \multirow[t]{2}{*}{ Sample } & \multicolumn{3}{|c|}{ Bacterial count } & \multicolumn{3}{|l|}{ Fungal count } & \multirow{2}{*}{$\begin{array}{lr}\text { Storage } & \text { days } \\
\text { prior } & \text { to } \\
\text { visible } & \\
\text { spoilage } & \\
\end{array}$} \\
\hline & $\begin{array}{l}0 \text { day } \\
\left(\times 10^{3} \mathrm{cfu} / \mathrm{g}\right)\end{array}$ & $\begin{array}{l}2 \text { days } \\
\left(\times 10^{3} \mathrm{cfu} / \mathrm{g}\right)\end{array}$ & $\begin{array}{l}5 \text { days } \\
\left(\times 10^{3} \mathrm{cfu} / \mathrm{g}\right)\end{array}$ & $\begin{array}{l}0 \text { day } \\
\left(\times 10^{3} \mathrm{cfu} / \mathrm{g}\right)\end{array}$ & $\begin{array}{l}2 \text { days } \\
\left(\times 10^{3} \mathrm{cfu} / \mathrm{g}\right)\end{array}$ & $\begin{array}{l}5 \text { days } \\
\left(\times 10^{3} \mathrm{cfu} / \mathrm{g}\right)\end{array}$ & \\
\hline $\mathrm{SSB}_{0}$ & 7 & 22 & 61 & 9 & 28 & 76 & 6 \\
\hline $\mathrm{SSB}_{2}$ & 4 & 19 & 55 & 6 & 24 & 62 & 6 \\
\hline $\mathrm{SSB}_{3}$ & 2 & 13 & 50 & 4 & 17 & 57 & 6 \\
\hline $\mathrm{SSB}_{4}$ & 2 & 10 & 43 & 3 & 15 & 51 & 7 \\
\hline $\mathrm{SSB}_{5}$ & 1 & 7 & 36 & 3 & 13 & 45 & 8 \\
\hline $\mathrm{SSB}_{6}$ & $\mathrm{NG}$ & 8 & 24 & 2 & 9 & 31 & 8 \\
\hline
\end{tabular}

Values are means of duplicate determinations. $\mathrm{NG}=$ No growth, $\mathrm{SSB}_{0}=100 \mathrm{ml}$ Sugar solution treated-bread, $\mathrm{SSB}=80 \mathrm{ml}$ Sugar solution $+20 \mathrm{ml}$ Serendipity berry extract treated-bread, $\mathrm{SSB}_{3}=70 \mathrm{ml}$ Sugar solution $+30 \mathrm{ml}$ Serendipity berry extract treated-bread, $\mathrm{SSB}_{4}=60 \mathrm{ml}$ Sugar solution + $40 \mathrm{ml}$ Serendipity berry extract treated-bread, $\mathrm{SSB}_{5}=50 \mathrm{ml}$ Sugar solution $+50 \mathrm{ml}$ Serendipity berry extract treated-bread, SSB $6=40 \mathrm{ml}$ Sugar solution $+60 \mathrm{ml}$ Serendipity berry extract treated-bread.

\section{CONCLUSION}

The use of serendipity berry extract as sugar substitute could be applied not only to improve nutritional and sensory qualities but also to inhibit microbial growth and thus extend the shelf life of wheat flour bread. This study showed that serendipity berry extract could be used as natural sweetener and as a preservative in bread. The sensory study also indicated that highly acceptable bread could be produced by substituting sugar (5\% sugar solution) with $60 \%$ serendipity berry extract. This study therefore recommends serendipity berry extract as a natura sweetener and as a substitute for chemical preservatives in bread production and similar food applications.

\section{REFERENCES}

AACC. 2000. Approved Methods of the American Association of Cereal Chemists (10th Edition), Methods 10-10B, 26-21A, 44-19, 44-08, and 54-40A St. Paul, MN, USA: American Association of Cereal Chemists International. ABIODUN, O. A., AKINOSO, R. 2014. Physico-chemical properties of serendipity berry (Dioscoreophyllum cumminsii) fruit. Journal of Applied Science and Environmental Management, 18(2), 218-221.

ABIODUN, O. A., AMANYUNOSE, A. A., OLOSUNDE, O. O., ADEGBITE, J. A. 2014. Sugar and alkaloid profiles of serendipity berry. Food Science and Quality Management. 28, 83-89.

ADEBOWALE, A. A., SANNI, L. O., AWONORIN, S. O. 2005. Effect of texture modifiers on the physicochemical and sensory properties of dried fufu. Food Sci. Technol. Intl., 1(5), 373-382.

ADEGOKE, G. O. 2004. Understanding Food Microbiology, (2nd Edition). Ibadan: Aleliuia Ventures Ltd, 127-191 p.

AJANAKU, K. O., AJANAKU, C. O., EDOBOR-OSOH, A., NWINYI, O. C. 2012. Nutritive value of sorghum ogi fortified with groundnut seed (Arachis hypogeal). American Journal of Food Technology, 79, 82-88. http://dx.doi.org/10.3923/ajft.2012.82.88.

AOAC. 1990. Official methods of analysis of the AOAC (15th ed.), Methods 932.06, 925.09, 985.29, 923.03, Arlington, VA, USA: Association of Official Analytical Chemists.

AOAC. 2000. Official Methods of Analysis of the Association of Official Analytical Chemists (25th ed.), Washington D. C., USA: Association of Official Analytical Chemists.

ARISE, A. K., DAUDA, A. O., AWOLOLA, G. V., AKINLOLU-OJO, T. V. 2017. Physicochemical, functional and pasting properties of composite flour made from wheat, plantain and bambara for biscuit production. Annals. Food Science and Technology, 18(4), 616-624.

AXEL, C., ZANNINI, E., ARENDT, E. K. 2017. Mould spoilage of bread and its biopreservation: a review of current strategies for bread shelf life extension. Critical Reviews in Food Science and Nutrition, 57(16), 3528-3542. http://dx.doi.org/10.1080/10408398.2016.1147417.

BHISE, S., KAUR, A. 2014. Baking quality, sensory properties and shelf life of bread with polyols. J. Food Sci. Technol., 51(9), 2054-2061. http://dx.doi.org/10.1007/s13197-014-1256-3.

CORREIA, P. M. R., GONZAGA, M., BATISTA, L. M., BEIRÃO-COSTA, L. GUINÉ, R. F. P. 2015. Development and characterization of wheat bread with lupin flour. International Journal of Biological, Biomolecular, Agricultural, Food and Biotechnological Engineering, 9(10), 923-927.
CUMMINGS, J. H., BEATTY, E. R., KINGMAN, S. M., BINGHAM, S. A ENGLYST, H. N. 1996. Digestion and physiological properties of resistant starch in the human bowel. Brit. J. Nutr., 75, 733.

DAUDA, A. O., ABIODUN, O., MAIYAKI, T., KAYODE, R. M. O. 2017 Microbiological evaluation of watermelon juice treated with serendipity berry (Dioscoreophyllum cumminsii) extract. Croatian Journal of Food Science Technology, 9(1), 19-24. http://dx.doi.org/10.17508/CJFST.2017.9.1.03.

EKUNSEITAN, O. F., OBADINA, A. O., SOBUKOLA, O. P., OMEMU, A. M., ADEGUNWA, M. O., KAJIHAUSA, O. E., ADEBOWALE, A. A., SANNI, S. A., SANNI, L. O., KEITH, T. 2016. Nutritional composition, functional and pasting properties of wheat, mushroom, and high quality cassava composite flour. Journal of food processing and preservation, 1-8. http://dx.doi.org/10.1111/jfpp.13150.

FARUYA, J., TAKAFUMI Y., KIYOHARA, H., 1983. Alkaloid production in cultured cells of Dioscoreophyllum cumminsii. Phytochemistry, 22, 1671-1673 https://dx.doi.org/10.1016/0031-9422(83)80108-3

HO, L. H., ABDUL AZIZ, N. A., BHAT R., AZAHARI, B. 2013. Storage studies of bread prepared by incorporation of the banana pseudo-stem flour and the composite breads containing hydrocolloids. CyTA - Journal of Food, 12 (2), 141-149. http://dx.doi.org/10.1080/19476337.2013.806597.

IHEKORONYE, A. I., NGODDY, P. O. 1985. Integrated Food Science and Technology for the Tropics. London and Oxford: Macmillan Education Ltd., 105-112, 189-190, 343-351 p.

IJAH, U. J. J., AUTA, H. S., ADUlOJU, M. O., ARANSIOLA, S. A. 2014 Microbiological, nutritional, and sensory quality of bread produced from wheat and potato flour blends. International Journal of Food Science, 1-6. http://dx.doi.org/10.1155/2014/671701.

IKEGWU, O. J., NWOBASI, V. N., ODOH, M. O. AND OLEDINMA, N. U. 2009. Evaluation of the pasting and some functional properties of starch isolated from some improved cassava varieties in Nigeria. African Journal of Biotechnology, 8(10), 2310-2315.

INGLETT, G. E. 1976. A history of sweeteners-natural and synthetic. Journal of Toxicology and Environmental Health, 2(1), 207-214. https://dx.doi.org/10.1111/j.1365-2621.1969.tb12791.

INGLETT, G. E., MAY, J. F. 1969. Serendipity Berries-Source of a New Intense Sweetener. Journal of Food Science, 34, 408-411. http://dx.doi.org/10.1111/j.1365-2621.1969.tb12791.

KAYODE, R. M., JOSEPH, J. K., ADEGUNWA, M. O., DAUDA, A. O., AKEEM, S. A., KAYODE, B. I., BABAYEJU A. A., OLABANJI, S. O. 2017. Effects of addition of different spices on the quality attributes of tiger-nut milk (kunun-aya) during storage. Journal of Microbiology, Biotechnology and Food Sciences, 7(1), 1-6. http://dx.doi.org/10.15414/jmbfs.2017.7.1.1-6.

KUČEROVÁ, I. J. 2015. Technology of cereals. Praha: Mendel University in Brno, Zemědělská, 112 p., ISBN 978-80-7509-343-1.

MAGAN, N., KESHRI, G., NEEDHAM, R., SNEATH, R. 2003. Use of electronic nose technology for the early detection of spoilage moulds in cereal products. In: Credland, P. F., Armitage, D. M., Bell, C. H., Cogan, P. M., Highley, E. (Editors), Advances in Stored Product Protection. CABI PUBLISHING: Cambridge, MA 02139 USA, 139-143 p.

MENTES, O., ERCAN, R., AKCELIK, M. 2007. Inhibitor activities of two Lactobacillus strains, isolated from sourdough, against rope-forming Bacillus strains. Food Control, $18(4), \quad 359-363$ https://dx.doi.org/10.1016/j.foodcont.2005.10.020. 
OBIEGBUNA, J. E., AKUBOR, P. I., ISHIWU, C. N., NDIFE, J. 2013. Effect of substituting sugar with date palm pulp meal on the physicochemical, organoleptic and storage properties of bread. Afr. J. Food Sci., 7(6), 113-119. https://dx.doi.org/10.5897/AJFS2012.0605.

OLAOYE, O. A., ONILUDE, A. A. 2008. Microbiological, proximate analysis and sensory evaluation of baked products from blends of wheat-breadfruit flours. African Journal of Food, Agriculture, Nutrition and Development, 8(2), 192-203. ONWELUZO, J. C., NNAMUCHI, O. M. 2009. Production and evaluation of porridge type breakfast product Trecuila africana and sorghum bicolour flours. $\begin{array}{llll}\text { Pakistan Journal of Nutrition, } & 8,\end{array}$ https://dx.doi.org/10.3923/pjn.2009.731.736.

OSELEBE, H. O., NWANKITI, O. C. 2005. Cytology of root tips of Dioscoreophyllum cumminsii (Stapf) Diel. Agro-Sci., 4(1), 43-45 http://dx.doi.org/10.4314/as.v4i1.1521.

PATERAS, I. M. C. 1999. Bread spoilage and staling. In: Technology of breadmaking, Cauvain, S. P., Young, L. S. (Eds.). Boston MA: Springer, 240-261 p. https://dx.doi.org/10.1007/978-1-4757-6687-5_10.

PENARRUBIA, L., KIM, R., GIOVANNONI, J., KIM, S. H., FISCHER, R. L. 1992, Production of the sweet protein monellin in transgenic plants. Bio. Technology, 10(5), 561-564. https://dx.doi.org/10.1038/nbt0592-561.

PETER, I. A., OKAFOR, D. C., KABUO, N. O., IBEABUCHI, J.C., ODIMEGWU, E. N., ALAGBAOSO, S. O., NJIDEKA, N. E., MBAH, R. N. 2017. Production and evaluation of cookies from whole wheat and date palm fruit pulp as sugar substitute. Int J Adv Eng Technol Manage Appl Sci., 4(4): 1-31.

SANNI, L. O., ADEBOWALE, A. A., TAFA, S. O. 2006. Proximate, functional, pasting and sensory qualities of instant yam flour. A paper presented at the 14 ISTRC Symposium, Central Tuber Crops the Research Institute, Trivandrum, Kerala State, India.

SANNI, L. O., IKUOMOLA, D. P., SANNI, S. A. 2001. Effect of length of fermentation and varieties on the qualities of sweet potato gari. Akoroda, M. O (editor), Proceedings of the 8th triennial Symposium of the International Society for Tropical Root Crops. Africa Branch (ISTRC-AB), IITA, Ibadan: Nigeria, 208-211.

SHIMELIS, A. E., MEAZA, M., RAKSHIT, S. 2006. Physico-chemical properties, pasting behaviour and functional characteristics of flours and starches from improved bean (Phaseolus Vulgaris L.) varieties grown in East Africa. CIGR Ejournal, 8, 1-18.

SHITTU, T. A., LASEKAN, O. O., SANNI, L. O., OLADOSU, M. O. 2001. The effect of drying methods on the functional and sensory characteristics of pukurua fermented cassava product. An International Journal of Agricultural Sciences, Sciences, Environment and Technology, 1(2), 9-16.

WILSON, G. F. 1987. Status of banana and plantain breeding strategies. Persley, G. J., De Langhe, E. (editors), Proceeding of an International workshop, Cairns: Australia.

WLODAWER, A, HODGSON, K. O. 1975. Crystallization and Crystal Data of Monellin. Proceedings of the National Academy of Sciences of the United States of America, 72, 398-9. 